\title{
PEMANFAATAN MODEL TOPSIS UNTUK PEMILIHAN PRODUK KERAJINAN DALAM MENINGKATKAN KEUNGGULAN DAN KEARIFAN LOKAL
}

\author{
Rina Fiati \\ Fakultas Teknik, Program Studi Teknik Informatika \\ Universitas Muria Kudus \\ Email: rina.fiati@umk.ac.id \\ Ahmad Abdul Chamid \\ Fakultas Teknik, Program Studi Teknik Informatika \\ Universitas Muria Kudus \\ Alif Catur Murti \\ Fakultas Teknik, Program Studi Teknik Informatika \\ Universitas Muria Kudus
}

\begin{abstract}
ABSTRAK
Pemerintah daerah pelu melakukan persiapan dalam rangka menghadapi Pasar ASEAN, masih banyak peluang UMKM untuk meraih pangsa pasar dan peluang investasi. Guna memanfaatkan peluang tersebut, maka tantangan yang terbesar bagi UMKM di Indonesia menghadapi pasar Bebas ASEAN adalah bagaimana mampu menentukan strategi yang tepat guna memenangkan persaingan. Salah satu solusinya adalah memunculkan produk unggulan dari industri kerajinan tradisional tanah liat yang sampai sekarang masih berkembang dan merupakan warisan budaya bangsa turun-temurun. Kerajinan ini memiliki kearifan lokal yang perlu dijaga kelestariannya. Semula jumlah objek produk penelitian umkm terbagi menjadi 4 jenis yaitu produk tas, pisau, batik, dan tanah liat, tetapi peneliti menemukan beberapa fakta bahwa produk kerajinan dari industri kerajinan tanah liat memiliki banyak jenis produk dan belum pernah masuk dalam kategori produk unggulan daerah di kabupaten kudus, karena itu produk dari tanah liat dijadikan objek penelitian. Hasil yang diperoleh untuk menentukan prioritas produk kerajinan tanah liat digunakan sistem pendukung keputusan dengan menerapkan metode Technique For Others Reference by Similarity to Ideal Solution (TOPSIS). Pemilihan Dalam menentukan prioritas produk kerajinan digunakan lima (5) kriteria diantaranya : Jumlah Unit Usaha, Jumlah Tenaga Kerja, Nilai Produksi, Nilai Investasi, Nilai Kompetitif. Hasil dari penelitian ini dapat dijadikan bahan rujukan atau bahan pertimbangan oleh dinas terkait dalam menentukan produk unggulan daerah, khususnya industri tanah liat yang dalam sejarahnya belum pernah menghasilkan salah satu produknya menjadi produk unggulan kabupaten Kudus.
\end{abstract}

Kata kunci: TOPSIS; UMKM; produk unggulan; sistem; keputusan.

\begin{abstract}
Local governments need to prepare in order to face the ASEAN Market, there are still many opportunities SMEs to gain market share and investment opportunities. To take advantage of these opportunities, the greatest challenge for SMEs in Indonesia face the ASEAN Free market is how to be able to determine the right strategy to win the competition. One solution is to bring out superior products from the traditional clay craft industry which until now is still developing and is a hereditary cultural heritage. These craft have local knowledge that needs to be preserved. Initially the number of UMKM research products was divided into 4 types, namely bags, knives, batik, and clay, but the researchers found several facts that handicraft products from the clay craft industry had many types of products and had never been included in the regional superior product categories in Kudus District, because that product from clay is the object of researchResults obtained to determine the priority of clay craft products used decision support system by applying the method Technique For Others Reference by Similarity to Ideal Solution (TOPSIS). In determining priority of handicraft products used five (5) criteria are: Number of Business Units, Total Labor, Value of Production, Investment, Competitive Value. The results of this study can be used as reference material or material for consideration by the relevant agencies in determining the superior product, especially clay industry that historically has never produced one of the products become the flagship product of the Holy district Kabupaten Kudus.
\end{abstract}

Keywords: TOPSIS; UMKM; featured product; systems; decision. 


\section{PENDAHULUAN}

Kearifan lokal merupakan sesuatu yang berkaitan secara spesifik dengan budaya tertentu (budaya lokal) dan mencerminkan cara hidup suatu masyarakat tertentu (masyarakat lokal). Dengan kata lain, kearifan lokal bersemayam pada budaya lokal (local culture). Budaya lokal adalah budaya yang dimiliki oleh masyarakat yang menempati lokalitas atau daerah tertentu yang berbeda dari budaya yang dimiliki oleh masyarakat yang berada di tempat yang lain. Di Indonesia istilah budaya lokal juga sering disepadankan dengan budaya etnik/ subetnik. Setiap bangsa, etnik, dan subetnik memiliki kebudayaan yang mencakup tujuh unsur, yaitu: bahasa, sistem pengetahuan, organisasi sosial, sistem peralatan hidup dan teknologi, sistem mata pencaharian, sistem religi, dan kesenian. Keunggulan kompetitif (competitive advantage) adalah suatu kemampuan perusahaan untuk bersaing lebih unggul dibandingkan kompetitor. Menurut Porter, bisnis dapat dikembangkan untuk mengarah kepada competitive advantage dengan menggunakan salah satu dari dua strategi: low cost strategy atau differentiation strategy. Low cost strategy memfokuskan pada terciptanya low cost relatif terhadap pesaing. Sedangkan differentiation strategy memfokuskan pada penciptaan keunikan dalam pandangan pelanggan. Keunikan produk dapat diciptakan dengan berbagai pendekatan, seperti brand loyalty, superior customer service, dealer network, desain dan fitur produk, atau teknologi.

Kearifan Lokal dilihat dari kamus Inggris Indonesia terdiri dari dua kata, yaitu kearifan (wisdom) dan lokal (local). Local berarti setempat, sementara wisdom sama dengan kebijaksanaan. Dengan demikian maka dapat dipahami, bahwa pengertian kearifan lokal merupakan gagasan-gagasan atau nilainilai, pandangan-padangan setempat atau (lokal) yang bersifat bijaksana, penuh kearifan, bernilai baik yang tertanam dan diikuti oleh anggota masyarakatnya. Berdasarkan Peraturan menteri dalam negeri nomor 9 tahun 2014 tentang pedoman pengembangan produk unggulan daerah bab 1 pasal 1 butir 3 menyatakan bahwa yang memiliki wewenang untuk mengembangkan produk unggunalan daerah yakni pemerintah daerah adalah gubernur, bupati, atau walikota, dan perangkat daerah sebagai unsur penyelenggara pemerintah daerah [1]. Penelitian yang dilakukan oleh Zhu Xiaoqian dkk, menggunakan metode Technique For Others Reference by Similarity to Ideal Solution (TOPSIS) untuk analisis data agar dihasilkan prioritas produk kerajinan. Metode Technique For Others Reference by Similarity to Ideal Solution (TOPSIS) telah banyak diterapkan dalam sistem pendukung keputusan, salah satunya diimplementasikan untuk menentukan kualitas kredit yang ada di Cina, metode (Technique For Others Reference by Similarity to Ideal Solution) [2]. TOPSIS dipilih dengan alasan tidak adanya metode kuantitatif yang digunakan untuk mengevaluasi kualitas kredit, dari analisis percobaan memverifikasi bahwa kualitas sistem indikator kredit yang diusulkan dapat diandalkan dan TOPSIS cocok untuk evaluasi kualitas kredit.

\subsection{Kerangka Teori}

Menurut Olson,D.L.,2004, bahwa metode Technique For Others Reference by Similarity to Ideal Solution (TOPSIS) pertama kali diperkenalkan oleh Hwang dan Yoon [3]. TOPSIS merupakan metode multikriteria untuk mengidentifikasi dari himpunan alternatif terbatas berdasarkan meminimalkan jarak titik ideal terjauh dan memaksimalkan jarak titik ideal terendah. Langkah-langkah metode TOPSIS sebagai berikut [4]:

a) Menentukan matriks keputusan yang ternormalisasi

$$
r_{i j}=\frac{x_{i j}}{\sqrt{\sum_{j=1}^{m} x_{i j}^{2}}},(i=1,2, \ldots, n ; j=1,2, \ldots, m)
$$

Keterangan :

xij merupakan rating kinerja alternatif ke-i terhadap atribut ke-j, rij adalah elemen dari matriks keputusan yang ternormalisasi, $\mathrm{n}$ adalah elemen alternatif, $\mathrm{M}$ adalah element atribut.

b) Menentukan matriks keputusan yang terbobot

$$
y=\left[\begin{array}{cccc}
y_{11} & y_{12} & \ldots & y_{i j} \\
y_{21} & y_{22} & \ldots & y_{2 j} \\
\vdots & \vdots & \ddots & \vdots \\
y_{i 1} & y_{i 2} & \ldots & y_{i j}
\end{array}\right] \text { untuk } y_{i j}=w_{j} r_{i j}
$$

keterangan:

wj adalah bobot dari kriteria ke-j

yij adalah elemen dari matriks keputusan yang ternormalisasi terbobot 
c) Menentukan matriks solusi ideal positif (A+) dan matriks solusi ideal negatif (A-)

$$
\begin{aligned}
& A^{+}=\left(y_{1}{ }^{+}, y_{2}{ }^{+}, \cdots, y_{j}{ }^{+}\right) \\
& A^{-}=\left({y_{1}}^{-},{y_{2}}^{-}, \cdots, y_{j}{ }^{-}\right)
\end{aligned}
$$

dengan

$$
\begin{aligned}
& y_{j}{ }^{+}=\left\{\begin{array}{c}
\max y_{i j}, j i k a j=\text { keuntungan } \\
\min _{i} y_{i j}, \text { jika } j=\text { biaya }
\end{array}\right. \\
& y_{j}^{-}=\left\{\begin{array}{c}
\max y_{i j}, \text { jika } j=\text { keuntungan } \\
\min _{i} y_{i j}, \text { jika } j=\text { biaya }
\end{array}\right.
\end{aligned}
$$

Dalam penentuan kriteria :

Dapat dikatakan Benefit, jika nilai kriteria semakin besar maka lebih layak dipilih dan dapat dikatan Cost, jika nilai kriteria semakin kecil maka lebih layak dipilih.

d) Menentukan jarak nilai alternatif dari matriks solusi ideal positif (di+) dan matriks solusi ideal negatif (di-), jarak solusi ideal positif (di+)

$$
d_{i}^{+}=\sqrt{\sum_{j=1}^{m}\left(y_{i j}-y_{j}^{+}\right)^{2}}
$$

Keterangan :

$y_{j}{ }^{+}$adalah elemen dari matriks solusi ideal positif

$$
d_{i}^{-}=\sqrt{\sum_{j=1}^{m}\left(y_{i j}-y_{j}^{-}\right)^{2}}
$$

keterangan:

$y_{j}{ }^{-}$adalah elemen dari matriks solusi ideal negative

e) Menentukan nilai preferensi (ci) untuk setiap alternatif. Nilai preferensi merupakan kedekatan suatu alternatif terhadap solusi ideal

$$
c_{i}=\frac{d_{i}^{-}}{d_{i}{ }^{-}+d_{i}{ }^{+}}
$$

keterangan:

nilai ci yang lebih besar menunjukkan prioritas alternatif.

\subsection{Penelitian Terdahulu}

Penelitian yang dilakukan Setiya N.,dkk ,pada tahun 2006, menunjukan penelitian yang telah mengkaji penentuan produk kerajinan yakni penelitian yang dilakukan oleh Nugroho dan Wulandari, dalam penelitian tersebut telah diterapkan metode Multi Attribute Decision Making Simple Additive Weighting (MADM-SAW) untuk menentukan produk kerajinan unggulan di kabupaten klaten. Metode Multi Attribute Decision Making Simple Additive Weighting (MADM-SAW) digunakan untuk menentukan bobot masing-masing kriteria, dan menentukan industri kerajinan dengan peringkat terbaik [5]. Penelitian lain yang telah mengkaji produk unggulan daerah adalah penelitian yang dilakukan oleh Eko Handoyo., dkk menjelaskan pentingnya penentuan produk unggulan daerah , karena tuntutan perkembangan zaman. Dalam penelitiannya menggunakan metode entropy dan ELECTRE II untuk menentukan produk unggulan. Hasil penelitian yang dilakukan menunjukan hasil akurasi sistem sebesar $30 \%$ [6]. Penelitian lain yang menunjukkan pentingnya penentuan produk unggulan daerah adalah penelitian yang dilakukan oleh Driska., dkk pada tahun 2016. Pada penelitiannya menggunakan metode AHP (Analytical Hierarchy Process) dan MPE (Metode Perbandingan Eksponensial ), dimana menghasilkan produk unggulan berupa minuman sari pala di daerah Bogor untuk sektor Industri Argo[7]. Dari 3 penelitian yang sudah dilakukan, masing-masing menggunakan acuan kriteria yang sama yaitu berdasarkan peraturan menteri dalam negeri nomor 9 tahun 2014 tentang pedoman pengembangan produk unggulan daerah. 
Untuk menentukan produk kerajinan unggulan digunakan lima kriteria diantaranya: unit usaha, tenaga kerja, nilai produksi, nilai investasi, nilai kompetitif. Penentuan kriteria ini sudah dikaji dengan peraturan kemendragi tentang produk unggulan sehingga sudah dapat dijadikan acuan untuk kompetisi dilevel ASEAN. Perbedaan penelitian ini dengan penelitian sebelumnya terletak pada metode yang digunakan dalam sistem pendukung keputusan dan objek penelitian tentunya beda. Selain itu perbedaan yang signifikan terlihat dalam analisis data yang hasilnya nanti akan menampilkan prioritas produk kerajinan kabupaten kudus yang berpotensi menjadi produk unggulan daerah kabupaten Kudus [8].

\section{METODOLOGI PENELITIAN}

\subsection{Pendekatan yang digunakan}

a) Identifikasi Masalah

Pada tahapan ini dilakukan identifikasi masalah yang ada, yakni melakukan kajian yang menyeluruh apa yang terjadi dilapangan yakni tepatnya di industri kerajinan yang ada di kabupaten kudus. Selain mengkaji dilapangan juga mengkaji literatur-literatur yang ada mengenai metode TOPSIS yang diterapkan dalam sistem pendukung keputusan, sehingga didapatkan permasalahan menentukan prioritas produk kerajinan menggunakan metode TOPSIS

b) Pengumpulan Data

Data yang diperlukan dalam penelitian ini yakni kriteria-kriteria yang digunakan dalam menentukan prioritas produk kerajinan, dimana kriteria tersebut didapatkan dari jurnal yang pernah mengkaji mengenai prioritas produk kerajinan dan urnal yang mengkaji penentuan produk unggulan daerah. Selain itu diperlukan juga data-data dari masing-masing industri kerajinan yang selanjutnya bisa digunakan untuk analisis data. Selain data dari jurnal akan dikaji juga berdasarkan peranturan menteri dalam negeri nomor 9 tahun 2014 tentang pedoman pengembangan produk unggulan daerah.

c) Analisa dan Perancangn Sistem

Dalam analisa sistem akan dilakukan analisis data menggunakan metode TOPSIS, perhitungan menggunakan rumus metode topsis akan diterapkan sebelum membuat aplikasi.

\subsection{Teknik Sampling}

Berdasarkan dari hasil evaluasi dilapangan, peneliti melakukan survei terhadap UMKM yang memiliki potensi untuk menjadi produk unggulan. Kudus memiliki banyak UMKM berkembang dan dapat menghasilkan produk unggulan dan dapat meningkatkan kearifan lokal. Peneliti menemukan beberapa fakta bahwa produk kerajinan dari industri kerajinan tanah liat memiliki banyak jenis dan belum pernah masuk dalam kategori produk unggulan daerah di kabupaten kudus. Peneliti mengambil sampling industri kerajinan tanah liat di Industri Sokka Kudus Barokah Jaya menjadi objek sampling yang akan diteliti, karena memiliki produksi jenis produk tanah liat yang lengkap. Sampling ini dijadikan sebagai model dasar dalam implementasi metode TOPSIS.

\section{HASIL DAN PEMBAHASAN}

Data yang diperlukan dalam penelitian ini yakni lima kriteria yang digunakan dalam menentukan prioritas produk kerajinan meliputi jumlah unit usaha, jumlah tenaga kerja, nilai produksi, nilai investasi, nilai kompetitif [5]. Dari hasil pengisian data yang dilakukan oleh pemilik industri kerajinan, selanjutnya data tersebut akan dianalisis menggunakan metode Technique For Others Reference by Similarity to Ideal Solution (TOPSIS). Berikut merupakan data kriteria, bobot kriteria dan kaidah yang digunakan seperti terlihat pada Tabel 1.

Tabel 1. Data kriteria

\begin{tabular}{llllll}
\hline Kriteria & K1 & K2 & K3 & K4 & K5 \\
\hline Bobot & 20 & 13 & 34 & 6 & 27 \\
Kaidah & Benefit & Benefit & Benefit & Benefit & Cost \\
\hline
\end{tabular}

Keterangan :

$\mathrm{K} 1$ = Jumlah Unit Usaha

K2 = Jumlah Tenaga Kerja

K3 = Nilai Produksi

K4 = Nilai Investasi

K5 = Nilai Kompetitif 
Berikut merupakan data yang didapatkan dari pengisian oleh pemilik industri kerajinan tanah liat dapat dilihat pada Tabel 2.

Tabel 2. Data form pengisian pemilik industri

\begin{tabular}{cccccc}
\hline \multirow{2}{*}{ Alternatif } & \multicolumn{5}{c}{ Kriteria } \\
\cline { 2 - 6 } & K1 & K2 & K3 & K4 & K5 \\
\hline A1 & 3 & 7 & 24 & 50 & 1 \\
A2 & 1 & 2 & 12 & 25 & 1 \\
A3 & 1 & 2 & 5 & 5 & 1 \\
A4 & 1 & 2 & 4 & 5 & 1 \\
\hline
\end{tabular}

Keterangan:

A1 = Genteng Kudus Sokka Press Kodok

A2 = Genteng Sokka Kudus Mantili Besar

A3 = Batu Bata

A4 = Tembikar

Data dari Tabel 4.1 dan Tabel 4.2 selanjutnya akan digunakan untuk menentukan prioritas alternatif yang dianalisis menggunakan Metode TOPSIS, dalam analisis menggunakan metode TOPSIS terdapat langkah-langkah diantaranya:

a) Langkah-1 Menentukan matriks keputusan yang ternormalisasi

Dalam melakukan perhitungan data matriks ternormalisasi menggunakan persamaan 1. Tabel 3 menampilkan perhitungan akar normalisasi matriks dan 4 merupakan perhitungan Normalisasi matriks.

Tabel 3. Perhitungan akar normalisasi matriks

\begin{tabular}{cccccc}
\hline \multirow{2}{*}{ Alternatif } & \multicolumn{5}{c}{ Kriteria } \\
\cline { 2 - 6 } & K1 & K2 & K3 & K4 & K5 \\
\hline A1 & 9 & 49 & 576 & 2500 & 1 \\
A2 & 1 & 4 & 144 & 625 & 1 \\
A3 & 1 & 4 & 25 & 25 & 1 \\
A4 & 1 & 4 & 16 & 25 & 1 \\
Jumlah & 12 & 61 & 761 & 3175 & 4 \\
Akar & 3,4641 & 7,8102 & 27,5862 & 56,3471 & 2 \\
\hline
\end{tabular}

Tabel 4. Perhitungan normalisasi matriks

\begin{tabular}{cccccc}
\hline \multirow{2}{*}{ Alternatif } & \multicolumn{5}{c}{ Kriteria } \\
\cline { 2 - 6 } & $\boldsymbol{K 1}$ & $\boldsymbol{K} \mathbf{2}$ & $\boldsymbol{K 3}$ & $\boldsymbol{K 4}$ & $\boldsymbol{K 5}$ \\
\hline A1 & 0,866 & 0,8963 & 0,87 & 0,8874 & 0,5 \\
A2 & 0,2887 & 0,2561 & 0,435 & 0,4437 & 0,5 \\
A3 & 0,2887 & 0,2561 & 0,1812 & 0,0887 & 0,5 \\
A4 & 0,2887 & 0,2561 & 0,145 & 0,0887 & 0,5 \\
\hline
\end{tabular}

b) Langkah-2 Menentukan matriks keputusan yang terbobot

Dalam menentukan matriks keputusan yang terbobot menggunakan persamaan 2. Hasil dari perhitungan dapat dilihat pada tabel 5.

Tabel 5. Data matriks keputusan yang terbobot

\begin{tabular}{cccccc}
\hline \multirow{2}{*}{ Alternatif } & \multicolumn{5}{c}{ Kriteria } \\
\cline { 2 - 6 } & $\boldsymbol{K 1}$ & $\boldsymbol{K} \mathbf{2}$ & $\boldsymbol{K 3}$ & $\boldsymbol{K 4}$ & $\boldsymbol{K 5}$ \\
\hline A1 & 17,3205 & 11,6514 & 29,58 & 5,3241 & 13,5 \\
A2 & 5,7735 & 3,329 & 14,79 & 2,6621 & 13,5 \\
A3 & 5,7735 & 3,329 & 6,1625 & 0,5324 & 13,5 \\
A4 & 5,7735 & 3,329 & 4,93 & 0,5324 & 13,5 \\
\hline
\end{tabular}

c) Langkah-3 Menentukan matriks solusi ideal positif (A+) dan matriks solusi ideal negatif (A-) Dalam mencari nilai solusi ideal positif dan negatif menggunakan persamaan 4 dan 5 . Hasil perhitungan dapat dilihat pada tabel 6. 
Tabel 6. Matriks solusi ideal positif dan negatif

\begin{tabular}{cccccc}
\hline D+ & 17,3205 & 11,6514 & 29,58 & 5,3241 & 13,5 \\
\hline D- & 5,7735 & 3,329 & 4,93 & 0,5324 & 13,5 \\
\hline
\end{tabular}

d) Langkah-4 Menentukan Prioritas Alternatif

Dalam pennentian prioritas alternative adalah menggukur jarak solusi ideal positif dan negative menggunakan persamaan 6 dan 7. Setelah didapatkan nilai jarak solusi ideal positif dan negative maka dapat menggunakan persamaan 8 untuk menghitung nilai preferensi sebagai dasar penentuan prioritas. Hasil perhitungan prioritas dapat dilihat pada tabel 7.

Tabel 7. Hasil prioritas alternatif

\begin{tabular}{cc}
\hline Alternatif & Hasil \\
\hline A1 & 1 \\
A2 & 0,3277 \\
A3 & 0,0424 \\
A4 & 0 \\
\hline
\end{tabular}

Pada tabel 4.8 dapat diketahui bahwa prioritas alternatif (A1 = Genteng Kudus Sokka Press Kodok) dengan nilai 1,0000 menjadi prioritas utama berdasarkan hasil analisis menggunakan metode TOPSIS.

\section{KESIMPULAN}

Sistem pendukung keputusan yang telah dibuat dapat menentukan prioritas produk kerajinan khususnya bagi industri kerajinan tanah liat. Hasil dari sistem ini dapat menjadi potensi produk unggulan dan kearifan lokal kabupaten Kudus. Sample penelitian ini menggunakan industri kerajinan tanah liat dimana memiliki potensi untuk berkembang dan bersaing. Berdasarkan analisis data menggunakan metode TOPSIS menghasilkan prioritas produk dengan nama Genteng Kudus Sokka Press Kodok menjadi alternatif utama dengan nilai preferensi satu (1). Implikasi dari penelitian ini adalah Produk Genteng Kudus Sokka Press Kodok menjadi produk unggulan daerah dan dapat mengangkat Kearifan lokal dan mencerminkan cara hidup suatu masyarakat tertentu (masyarakat lokal), serta mendorong pemerintah daerah untuk membantu mengembangkan produk unggulan dalam bidang pembuatan kebijakan, aturan birokrasi , memberikan pelatihan tenaga kerja sebagai bentuk untuk meningkatkan kualitas dan kuantitas produksi.

\section{DAFTAR PUSTAKA}

[1] Mentri Dalam Negeri, Pedoman Pengembangan Produk Unggulan Daerah. 2014.

[2] X. Zhu et al., "TOPSIS method for quality credit evaluation: A case of air-conditioning market in China," J. Comput. Sci., pp. 1-7, 2013.

[3] C. Hwang and K. Yoon, Multiple Attribute Decision Making: Methods and Applications, A State of the Art Survey, vol. 1. 1981.

[4] N. D. Prasongko and R. Gernowo, "Metode Quality Function Deployment dan Fuzzy Topsis Untuk Sistem Pendukung Keputusan Pemilihan Perusahaan Penyedia Jasa Internet," vol. 02, pp. 137-144, 2015.

[5] S. Nugroho, "PENERAPAN METODE MADM-SAW DALAM PENENTUAN PRODUK," vol. 7, no. 1, pp. 163-168, 2016.

[6] R. Y. Eko Handoyo, Andharini Dwi Cahyani, "UNGGULAN DAERAH MENGGUNAKAN METODE ENTROPY," vol. 7, no. 1, pp. 22-27, 2014.

[7] D. N. Fasyah and H. K. Daryanto, "Penentuan Produk Unggulan Usaha Mikro Kecil Menengah Sektor Industri Agro di Kabupaten Bogor," vol. 11, no. 2, 2016.

[8] F. Rina, A. A. Chamid, and A. C. Murti, "Penentuan Prioritas Produk Kerajinan yang berpotensi menjadi produk unggulan menggunakan pemodelan TOPSIS.” Laporan Penelitian, UMK. 